\title{
Ecology and distribution of juvenile cod and haddock in relation to sediment type and bottom currents on eastern Georges Bank
}

\author{
R. Gregory Lough ${ }^{1}$, Page C. Valentine ${ }^{2}$, David C. Potter ${ }^{1}$, Peter J. Auditore ${ }^{1}$, \\ George R. Bolz ${ }^{1}$, John D. Neilson ${ }^{3}$, R. Ian Perry ${ }^{3}$ \\ ${ }^{1}$ National Marine Fisheries Service, Northeast Fisheries Center, Woods Hole, Massachusetts 02543, USA \\ ${ }^{2}$ U.S. Geological Survey, Woods Hole, Massachusetts 02543, USA \\ ${ }^{3}$ Marine Fish Division, Department of Fisheries and Oceans, St. Andrews, New Brunswick, Canada E0G 2 X0
}

\begin{abstract}
Recently-settled 0-group juvenile cod Gadus morhua and haddock Melanogrammus aeglefinus were observed by submersible dives and research bottom trawls to inhabit primarily a large pebble-gravel deposit located on the northeastern edge of Georges Bank at 70 to $100 \mathrm{~m}$ water depth. Pelagic juvenile gadids are widespread on the bank in late spring, but by late July, they have become demersal and are abundant only on the gravel bed. Coloration of the juveniles mimics the appearance of the pebble bottom, possibly making them less vulnerable to predation there than on the light-colored sand bottom of most areas of the bank. On the basis of these observations, we hypothesize that the gravel habitat favors their survival through predator avoidance and, possibly to a lesser extent, through increased prey abundance. In particular, the pebble-gravel deposit on northeastern Georges Bank supports the largest aggregations of demersal juveniles, and it may be essential to the recruitment success of the Georges Bank gadid population. By September, the young fish are no longer present on the gravel bed because night-time feeding forays off the bottom result in their transport southeastward in the clockwise current gyre on the bank. The study area is characterized by strong, rotary tidal currents. During the day, demersal juveniles remain within a few centimeters of the bottom in the boundary layer where currents are somewhat reduced and where they maintain their position by swimming continually into the current. At night, regardless of the current, they rise off the bottom to feed on invertebrates in the near-bottom water column. Abundance estimates of demersal juveniles based on research bottom trawls show variability related to fish size and time of day. When compared with estimates of juvenile abundance based on submersible observations, the trawl data underestimate the numbers of juvenile fish present. We expect a knowledge of the diel behavior, geographic location, and most favorable habitat of demersal 0-group juveniles will aid in the assessment and management of the Georges Bank gadid population.
\end{abstract}

\section{INTRODUCTION}

The Georges Bank Atlantic cod (Gadus morhua L.) and haddock (Melanogrammus aeglefinus L.) stocks are major components of the Northwest Atlantic fisheries of the United States and Canada (Brown 1987). Recruitment generally has been poor since the intensive fishing of the mid-1960's, and management of the gadid stocks has been difficult in recent years, particularly for haddock, because of extreme variability in the survival of their early life stages (Hennemuth et al. 1980). The northeastern area of Georges Bank is known to be an important spawning and nursery area for the 0-group juveniles as well as a preferred habitat for older year classes (Sherman et al. 1984, Overholtz 1985). Generally, peak spawning time for cod is late February-early March, and for haddock, early April (Lough 1984, Smith \& Morse 1985). Pelagic egg patches drift south and west at 2 to $7 \mathrm{~km} \mathrm{~d}^{-1}$ in a clockwise current gyre on the bank and hatch in 2 to $3 \mathrm{wk}$ at average spring temperatures. In May, continuing the pelagic drifting phase of their development, high concentrations of larvae can be found along the southern flank of Georges Bank in the area between the 50 to $100 \mathrm{~m}$ isobaths. In early June, larger larvae generally are widespread in the shoaler waters $k 60 \mathrm{~m}$ water depth) of the bank. Transformation to the pelagic juvenile stage occurs when the larvae are 2 to $3 \mathrm{~cm}$ in 
length, or 2 to 3 mo from hatching (Fahay 1983, Bolz \& Lough 1988).

Cod and haddock have similar development, and the transition from pelagic to demersal life occurs when juveniles are 4 to $6 \mathrm{~cm}$ in length, although considerable variability in length has been noted (Colton 1965, Scott 1984, Potter et al. 1989). The transition period is estimated to last, on average, about 1 mo (Koeller et al. 1986). By July, when the juveniles become demersal, and throughout autumn, the only significant aggregations of 0 -group demersal juveniles caught in research vessel bottom trawls are on a large pebble-gravel deposit on northeastem Georges Bank. Results of bottom and pelagic gear studies have indicated that young demersal juveniles have a marked migration pattern, moving off the bottom at night and returning by day (Colton 1965, Scott 1984, Potter et al. 1989). On the basis of data collected by submersibles and research trawlers in the summers of 1986 and 1987, we report significant new observations on the ecology of recently-settled juvenile cod and haddock on northeastern Georges Bank.

\section{METHODS}

The purpose of the combined submersible-trawler program was to determine the absolute abundance of demersal 0-group cod and haddock and their degree of aggregation in relation to bottom type and time of day. The 'Johnson-Sea-Link I' submersible completed 18 duves during the period 4 to 13 August 1986, and the 'Deita' submersible completed 32 dives from 25 to 31 July 1987 on northeastern Georges Bank. In both years, the study area was surveyed by the RV 'Delaware II', employing a standard research bottom trawl and methods described by Grosslein (1974) so as to locate suitable sites for observing juvenile fish. Bottom trawl operations also were undertaken around-the-clock at the primary study sites in conjunction with the submersible dives. In 1986, the primary dive site was located at $42^{\circ} 05.0^{\prime} \mathrm{N}$ lat., $66^{\circ} 20.0^{\prime} \mathrm{W}$ long.; and in 1987. the primary site was at $42^{\circ} 05.0^{\prime} \mathrm{N}$ lat., $66^{\circ} 40.0^{\prime} \mathrm{W}$ long These sites were characterized by high concentrations of juveniles, and dives were conducted during periods of 3 to $5 \mathrm{~d}$ to observe diel behavior near the bottom, estimate abundance, and relate these observations to the results of research bottom-trawl catches. Normally, each day two $3 \mathrm{~h}$ dives were conducted using the 'Johnson-Sea-Link I', and 4 to $6 \mathrm{l} \mathrm{h}$ dives using the 'Delta' submersible. A moored acoustic pinger was deployed at the primary site to serve as a homing device for the submersible so as to center the transect observations within a restricted area. The submersible was tracked by the support ship and its path plotted on charts from Loran-C positions to estimate transect distances. Visibility for identification generally was good over a distance of 8 to $10 \mathrm{~m}$ from the submersible; a $6 \mathrm{~m}$ swath to $1 \mathrm{~m}$ above the bottom was used for standardizing the transect counts. Quantitative transect counts of the fish were made for periods of 10 to $30 \mathrm{~min}$, and these were standardized to numbers of individuals per $10000 \mathrm{~m}^{2}$ for comparison with the bottom trawl catches. Current speed within $3 \mathrm{~m}$ of the bottom was estimated in 1986 by a Savonius rotor mounted $2.4 \mathrm{~m}$ above the bottom on the 'Johnson-Sea-Link I', and in 1987 by a prototype current meter array designed to orient into the tidal current and make continuous direction and flow measurements at $20 \mathrm{~cm}, 1 \mathrm{~m}$, and $3 \mathrm{~m}$ above the bottom. Interpretation of sedimentary environments is based on seismic surveys, benthic grab samples, visual observations from submersibles, and on previous studies by other investigators.

\section{RESULTS}

\section{Near-bottom observations on juvenile cod and haddock}

A strong, semidiurnal, rotary tidal current flows northwest and southeast across Georges Bank (Brown \& Moody 1987) and is a major environmental factor that shapes the ecology of the habitat and structures the life histories of the many organisms living there. The nearbottom boundary current, even though reduced within the bottom meter, has a galvanizing force on juvenile fish behaviour, analogous to trout stemming the current in a stream. Juvenile cod and haddock orient into the current, swimming continually, which requires an expenditure of energy (Fig. 1). We have not yet been able to obtain a continuous record of the near-bottom current speed and its variability over a tidal cycle. Data collected during our submersible dives fall within the shaded zone in Fig. 2. Tidal current at $10 \mathrm{~cm}$ off the bottom is estimated to range from 1 to $5 \mathrm{~cm} \mathrm{~s}^{-1}$, and at $1 \mathrm{~m}$ off the bottom it ranges from 7 to $24 \mathrm{~cm} \mathrm{~s}^{-1}$ By using the relationship between the fishes' tail-beat frequency and swimming velacity " for a given length of fish, we estimated (based on video tape records) that a stationary $4 \mathrm{~cm}$ fish with a tail beat of 4 to 12 beats $\mathrm{s}^{-1}$ was swimming in a current of 6 to $23 \mathrm{~cm} \mathrm{~s}^{-1}$ near the bottom. A $7 \mathrm{~cm}$ fish was estimated to be swimming in a current of 3 to $1.3 \mathrm{~cm} \mathrm{~s}^{-1}$. Laboratory studies of sustained swimming speeds (Tyler 1978) show that fish

\footnotetext{
- Geñeral equation for continual or intermittent swimming in anchovy larvae: $V / A=-1.1+1.59 \mathrm{~F}$; where $\mathrm{V}=$ speed in $\mathrm{cm} \mathrm{s}^{-1} ; \mathrm{A}=$ tail-beat amplitude in $\mathrm{cm}(=1 / 5$ of body length); $F=$ tail-beat frequency (Hunter 1972)
} 


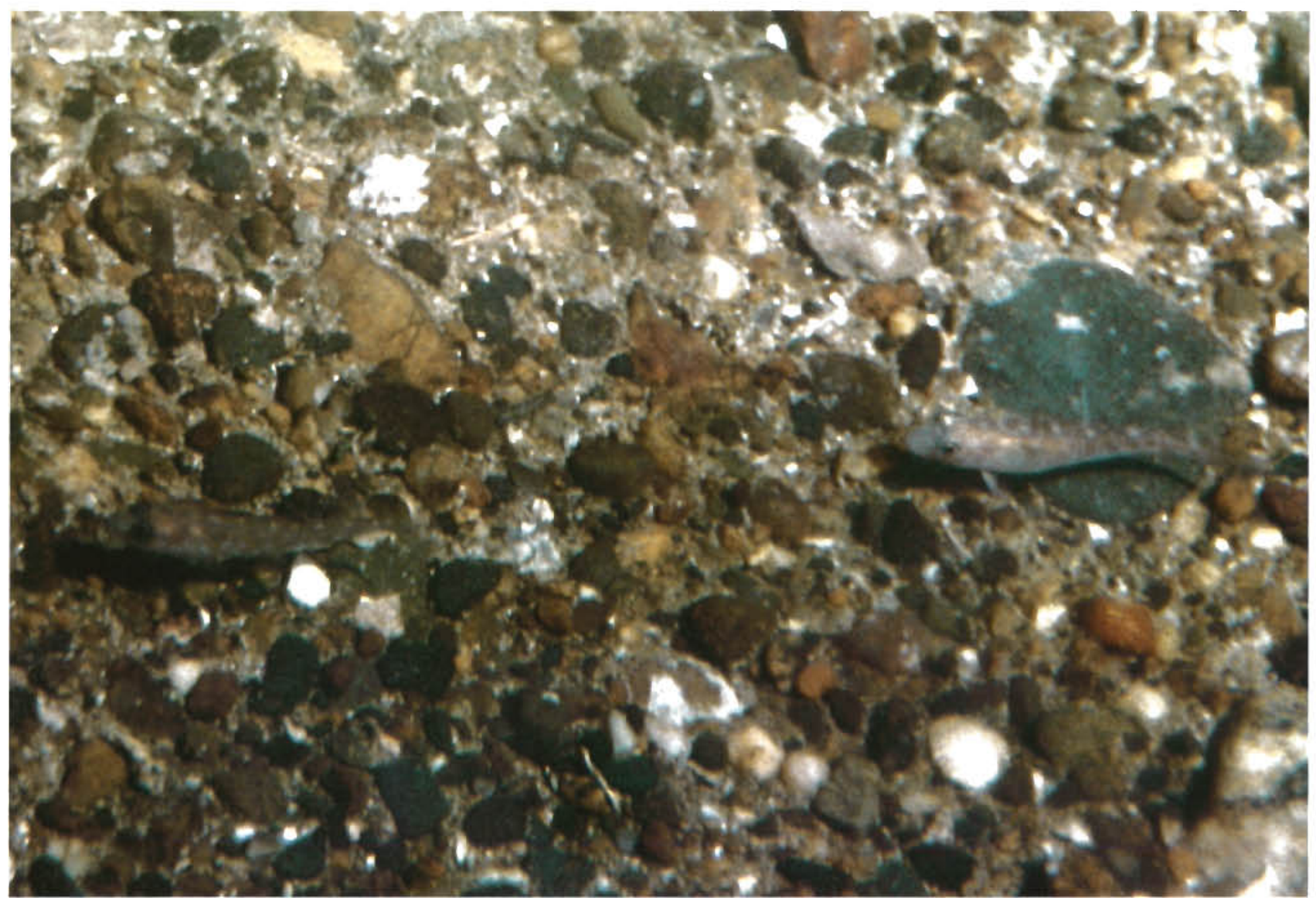

Fig. 1. Gadus morhua. Two juveniles about $5 \mathrm{~cm}$ in length on pebble-gravel bottom oriented into the current. 'Delta' submersible dive no. 828, 28 July 1987, 19:39 h (EST) on northeastern Georges Bank, 73 m water depth. Note similar mottled appearance of fish and pebble-gravel bottom

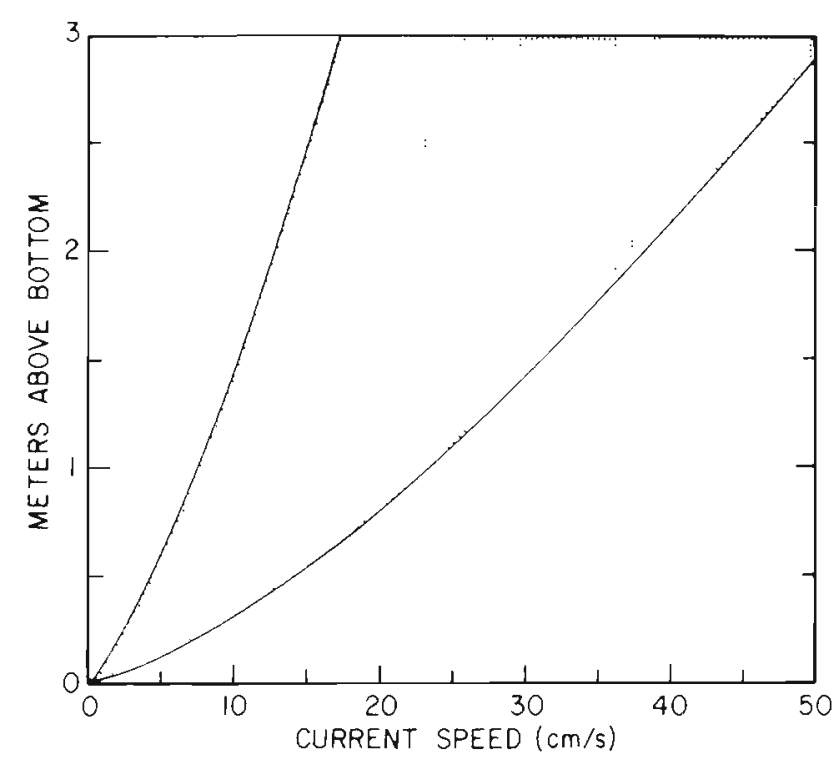

Fig. 2. Range of near-bottom current speeds measured in this study on northeastern Georges Bank dive sites, enclosed by shaded area move ca 2 body lengths $5^{-1}$ at $5^{\circ} \mathrm{C}$, which is within a degree of the bottom temperature measured on northeastern Georges Bank. Using this approximate relationship, a fish 4 to $7 \mathrm{~cm}$ long could maintain its position relative to the bottom in a current as high as 8 to 14 $\mathrm{cm} \mathrm{s}^{-1}$. These estimates of current speed in the bottom boundary layer are comparable to reported direct field measurements on eastern Georges Bank (Butman 1987).

In early August 1986, virtually no haddock were observed in the study area, but juvenile cod, ranging from 5 to $13 \mathrm{~cm}$ in length (mode $=7 \mathrm{~cm}$ ) were common and readily identifiable on the bottom (76 to $91 \mathrm{~m}$ water depth). During the day, young cod generally were within a few centimeters of the bottom and oriented into the strong tidal current. Their continual swimming into the current, even in the reduced velocity of the bottom boundary layer, allowed them to maintain their position relative to the bottom; sometimes moving laterally or retreating quickly by swimming up a short distance into the higher velocity current. This behavior made it relatively easy to count the number of fish 
along a transect as the submersible drifted along the bottom with the current. The average density of juvenile cod along the transects at the primary site was 498 ind. $10000 \mathrm{~m}^{-2}(\mathrm{CV}=99 \%)$ and patchy, with a range of 32 to 2067 ind. $10000 \mathrm{~m}^{-2}$ (Fig. 3A). After sunset, part of the population rose off the bottom ca 3 to
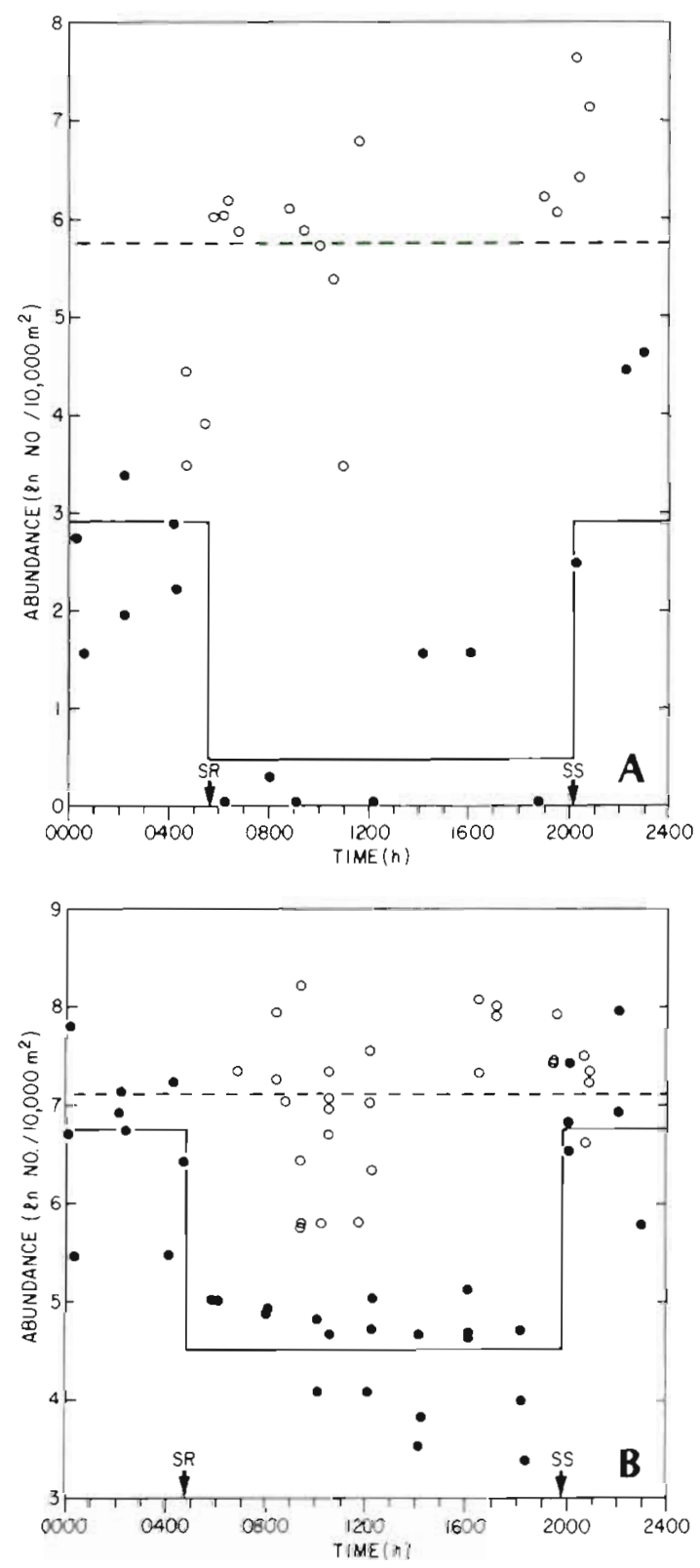

Fig. 3. Standardized abundance estimates of juvenile cod over a $24 \mathrm{~h}$ period. (A) Determined from 'Johnson-Sea-Link I' submersible transect observations (open circles) and research bottom trawl catches (solid circles) on northeastem Georges Bank, 4-11 Aug, 1986. SR = sunrise $; \mathrm{SS}=$ sunset. Dashed line: mean of submersible observations; solid line: mean of bottom trawl catches averaged over day and night-time periods. (B) From 'Delta' submersible transect observations and research bottom trawl catches on northeastem Georges Bank, 26-30 July, 1987 Symbols same as in (A)
$5 \mathrm{~m}$ and drifted passively in the current. This behavior could only be witnessed for a few moments during illumination following a short ( 3 to $5 \mathrm{~min}$ ) blackout period on the bottom. Juveniles observed above the bottom during these periods swam rapidly back to the bottom when lights were turned on. Analyses of stomach contents of cod collected by bottom trawls revealed they were feeding almost exclusively on small euphausiids (Meganyctiphanes norvegica), which were observed during submersible dives to be very abundant in the near-bottom water column after sunset.

In late July 1987, juvenile cod 3 to $7 \mathrm{~cm}$ in length (mode $=4 \mathrm{~cm}$ ) were collected in abundance during bottom trawl surveys on northeastern Georges Bank, while haddock juveniles 4 to $9 \mathrm{~cm}$ in length (mode $=$ $6 \mathrm{~cm}$ ) composed less than $5 \%$ of the gadid population. Based on observations from the submersible, both cod and haddock of this size appeared to have similar behavior near the bottom. However, it was difficult to discriminate the 2 species during transect counts. Hence, a small percentage of haddock probably are included with the counts of cod. The average density of the juvenile cod along the transects at the primary study site was 1540 ind. $10000 \mathrm{~m}^{-2}(\mathrm{CV}=62 \%)$ with a range of 310 to 3740 ind. $10000 \mathrm{~m}^{-2}$ (Fig. 3B). Their abundance was patchy and at times strongly clustered. As in the previous year, the juveniles resided by day within a few centimeters of the bottom and oriented into the tidal current. However, at somewhat reduced current at slack tide, they were farther off the bottom, and their direction of swimming appeared to be more random. At night, most juveniles were on the bottom, but some fish were several meters up in the water column, drifting along when tidal currents were flowing and swimming back to the bottom when startled by illumination. Presumably, they were feeding on invertebrates that were observed to move into the water column after sunset and on plankton. Stomach-content analyses of the juvenile cod and haddock from the bottom trawls showed them to be feeding predominantly on adult hyperiid amphipods (Themisto gaudichaudii).

A comparison of standardized research bottom trawl catches with the submersible transect counts on the same primary sites (Fig. 3) revealed an underestimation. of juvenile gadids by bottom trawling that fishery biologists have long suspected. Our results suggest a possible advantage of submersibles over trawls in estimating the abundance of demersal fish populations, as reported by Uzmann et al. (1977). In 1986, the average abundance of the population determined from bottom trawl catches was virtually nil (ln 0.49 ind. $10000 \mathrm{~m}^{-2}$ ) from sunrise to sunset, although higher at night (ln 2.93 ind $10000 \mathrm{~m}^{-2}$ ), but still at least an order 


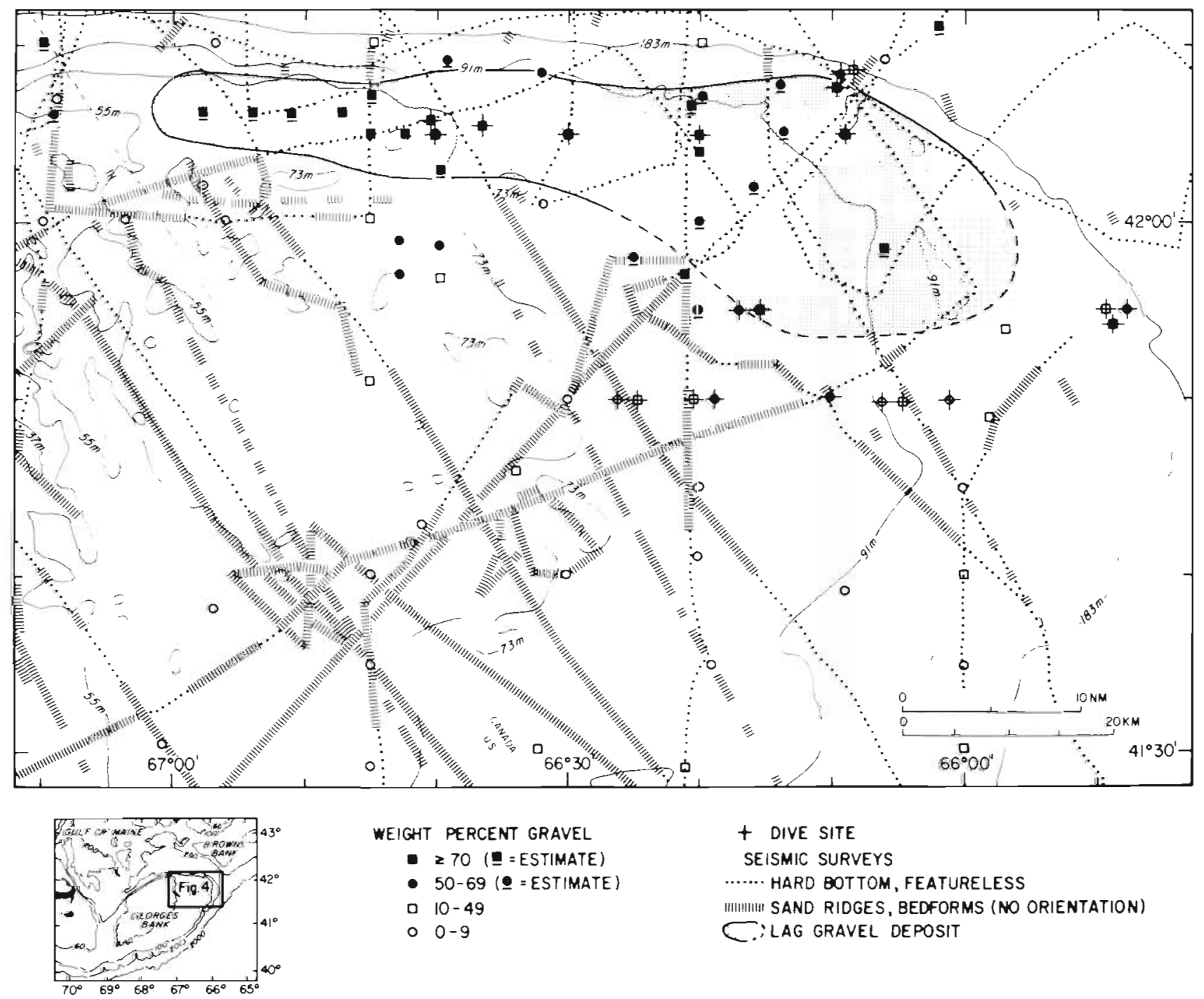

Fig. 4. Map of northeastern Georges Bank showing: areal extent of lag pebble gravel deposit; distribution of sediment samples and percent gravel by weight (Wigley 1961, Hathaway 1966, this study); and areas of hard, featureless bottom and of bedforms based on seismic surveys (Schlee 1973, Lewis et al. 1980, Twichell 1983, Fader et al. 1988, USGS unpubl.). Base is Canadian Hydrographic Chart L/C-8005 (Canadian Hydrographic Service 1985)

of magnitude lower than that determined from nighttime submersible counts (ln 5.75 ind. $10000 \mathrm{~m}^{-2}$ ). In 1987, the daytime bottom trawl average abundance (ln 4.51 ind. $10000 \mathrm{~m}^{-2}$ ) was higher than in 1986 , but still at least an order of magnitude lower than the average submersible estimates ( $\ln 7.12$ ind. $10000 \mathrm{~m}^{-2}$ ). However, the 1987 night-time bottom trawl estimates (ln 6.75 ind. $10000 \mathrm{~m}^{-2}$ ) were not significantly different than the submersible estimates. The larger modal size of cod in $1986(7 \mathrm{~cm})$, compared to that in $1987(4 \mathrm{~cm})$, may be related to the greater catch difference the first year. The larger fish appear to be more demersally oriented; they stay closer to the bottom both day and night and, consequently, are less vulnerable to the bottom trawl which, because of roller gear on the groundline, may easily over-run them.

\section{Georges Bank sedimentary environments}

Georges Bank is covered by sand and gravel of glacial origin (Schlee \& Pratt 1970, Schlee 1973). The bank is isolated from continental sediment sources by the Gulf of Maine to the north and by channels that cross the continental shelf on the east and west. Strong bottom currents transport sediment off the bank in all directions; they winnow silt- and clay-size particles, which at present make up less than $1 \%$ (by weight) of the surface sediment. The bank crest (less than $60 \mathrm{~m}$ water depth) is covered by sand ridges and other bedforms. The ridges are delineated on bathymetric maps (Fig. 4) and are oriented parallel to the strongest tidal flow (northwest and southeast). Sand waves and ripples are present on the flanks of the ridges and on 

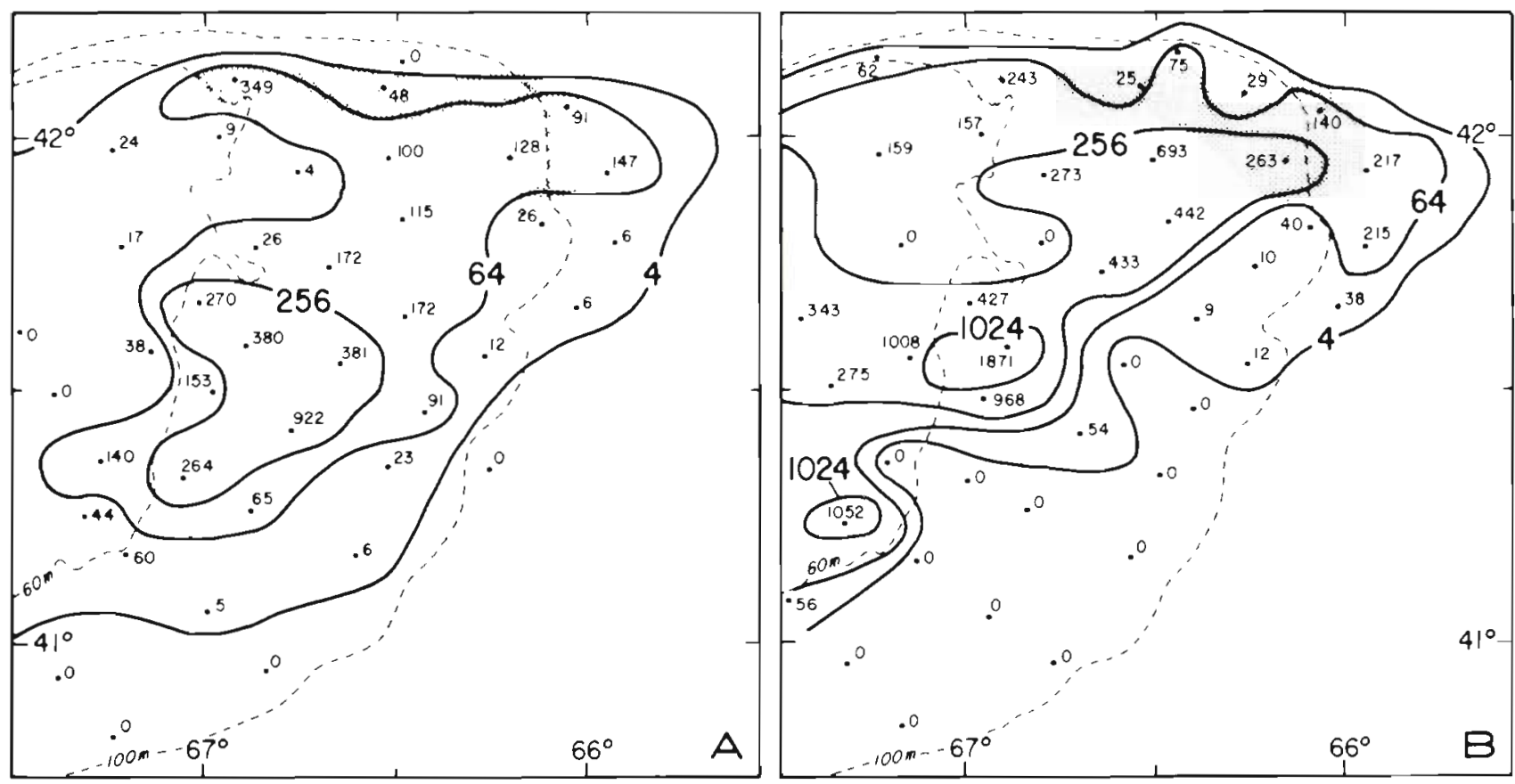

Fig. 5. Map of eastern Georges Bank showing distribution of pelagic juvenile cod (2 to $5 \mathrm{~cm}$ ). (A) 9-17 June, 1986; (B) 1-8 June, 1987. Cod were collected by 10-m MOCNESS gear (Potter et al. 1989), and catches were standardized to numbers of individuals per $1000 \mathrm{~m}^{2}$ Station abundances were contoured by factor level of 4 . The pebble gravel deposit is shaded

the seafloor between ridges and, generally, are oriented normal to the major tidal flow (Jordan 1962, Twichell 1983).

Sediment transport by rotary, semidiurnal tidal currents that reach average maximum near-bottom speeds of greater than $40 \mathrm{~cm} \mathrm{~s}^{-1}$ on the bank crest (Moody et al. 1984) is predominantly to the northwest and southeast. Storm currents on the bank crest have been observed to reach speeds of $1000 \mathrm{~cm} \mathrm{~s}^{-1}$ (20 knots) on a shoal area that is less than $10 \mathrm{~m}$ deep (Jordan 1962). The southern margin of the bank is covered by rippled sand which becomes finer with increasing water depth to the shelf edge at $200 \mathrm{~m}$. The northern shelf edge, at $100 \mathrm{~m}$ water depth, is closer to the bank crest, and much of it also is covered by rippled sand and by sand waves. However, a large area of the northeast part is covered by pebble gravel.

Three principal sedimentary environments are present on the eastern part of the bank: (1) pebble gravel; (2) sand formed into ripples and sand waves; (3) sand mixed with gravel between sand waves and in transition areas between rippled sand and pebble gravel deposits. The principal gravel deposit is located on the northeastern margin of the bank at depths of 70 to $100 \mathrm{~m}$ (Fig. 4). It extends to the east (from $67^{\circ} 02^{\prime} \mathrm{W}$ ) along the bank edge for ca $98 \mathrm{~km}$ ( $48 \mathrm{n}$ mile), and covers an area of $1130 \mathrm{~km}^{2}$ (330 $\mathrm{n} \mathrm{mile} \mathrm{e}^{2}$ ). The gravel contains from 70 to more than $90 \%$ gravel by weight, mostly pebble size $(0.4$ to $6.4 \mathrm{~cm})$. Smaller patches of gravel are present within the sand-dominated region to the south. During our dives, we observed that the gravel is a tightly-packed layer several particles deep that overlies mixed sand and gravel. We interpret the sea bottom to be a deposit of lag gravel from which sand has been winnowed by strong bottom currents. Locally, small patches of rippled sand are present on the gravel and appear to be temporary buildups in transit from the bank crest northward to the deeper waters of Georges Basin in the Gulf of Maine.

The gravel sea floor in this region is disturbed by fishing trawls and scallop dredges, both of which were active in the study area in August 1986 and in July 1987. In areas where fishing is not occurring, the gravel often is covered by erect ectoprocts (Bugula turrita) and encrusting polychaete worm tubes (Filograna implexa). In heavily fished areas, the bottom is furrowed, broken worm tubes are scattered over the seabed, and ectoprocts are absent. The dredging and trawling activity may help create the gravel seabed by mixing the sediment and allowing the gravel to migrate upward through finer sediment to become concentrated at the surface. The gravel bottom is mottled in color; it is made up of pink, brown, and gray clasts, reflecting the diverse rock sources of the glacially-derived sediment.

In the region south of the main lag gravel deposit, sand bedforms are abundant (Fig, 4). They are composed of well-sorted sand containing little or no gravel. Samples collected from dune crests $\left(41^{\circ} 50^{\prime} \mathrm{N}, 66^{\circ} 01^{\prime} \mathrm{W}\right.$ 


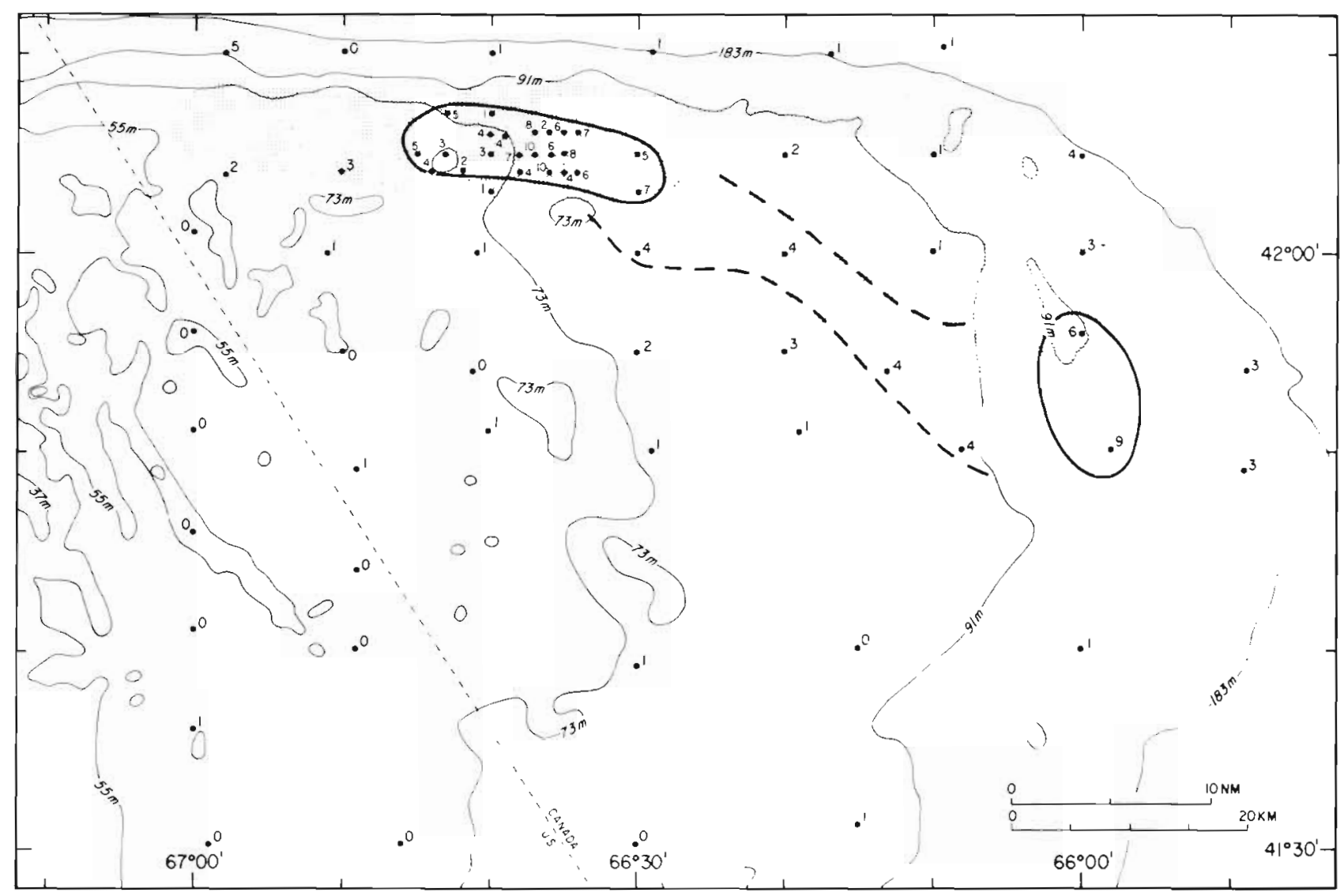

Fig. 6. Map of northeastern Georges Bank showing distribution of demersal juvenile cod from 25-31 July, 1987. Heavy solid lines outline 2 areas where 2 aggregations are present; one $\left(42^{\circ} 05^{\prime} \mathrm{N}\right.$ ) is restricted to the pebble gravel (shaded area), the other ( $41^{\circ} 50^{\prime}$ $\mathrm{N}$ ) is near the eastern end of the bank in an area of varied bottom types (see Fig. 4). Dashed lines: area where juvenile cod concentration is lower. Numerical categories at stations: juvenile cod individuals caught in standard research bottom trawls $(3.5$ knots for $30 \mathrm{~min}$ ) as follows: $0=0$ cod; $1=1$ to $5 ; 2=6$ to $10 ; 3=11$ to $20 ; 4=21$ to $50 ; 5=51$ to $100 ; 6=101$ to $200 ; 7=201$ to $300 ; 8=301$ to $400 ; 9=401$ to $500 ; 10=501$ to 700 . Highest catches occurred at night; all daytime catches were 26 ind. or less, except for one catch within the principal area of aggregation which was 62 ind. Where multiple trawls were made on the same station, the single highest catch is plotted

and $41^{\circ} 50^{\prime} \mathrm{N}, 66^{\circ} 24^{\prime} \mathrm{W}$ ) are 98 to $99 \%$ sand and have a median diameter of coarse to medium sand. We observed sand waves up to $2 \mathrm{~m}$ in height from the submersible. Seismic surveys have recorded sand waves ranging up to $8 \mathrm{~m}$ in height in the area shown in Fig. 4 ; the largest of them are located in the western part toward the bank crest (Fader et al. 1988). The bedforms are composed of quartz sand and are light in color; no epifauna was observed in the areas we visited. In the troughs between the bedforms, rippled sand mixed with gravel covers the seafloor. Gravel composes up to $50 \%$ of the sediment, and empty ocean quahog valves (Arctica islandica) and living scallops (Placopecten magellanicus) are present. The trough areas generally are similar in color to the sand waves.

In some places, adjacent to areas dominated by large bedforms, sand has been transported onto local deposits of gravel, and the mixture contains more than $50 \%$ gravel. Given the rapid movement of sand in the region, the inundation of a gravel patch may be shortlived; however, it is possible that it precedes the movement of large bedforms onto the gravel that will alter the bottom environment for a longer period of time. Gravel patches here are similar both in color and in associated epifauna to the main gravel deposit on the northern part of the bank described above.

\section{DISCUSSION}

\section{Survival of juvenile cod and haddock and the sedimentary environment}

Spawning of cod and haddock occurs on eastern Georges Bank, and the eggs, larvae, and pelagic juveniles generally drift to the south and southwest in the residual current. By June, the pelagic juvenile fish are widely distributed in patches over both the eastern and 


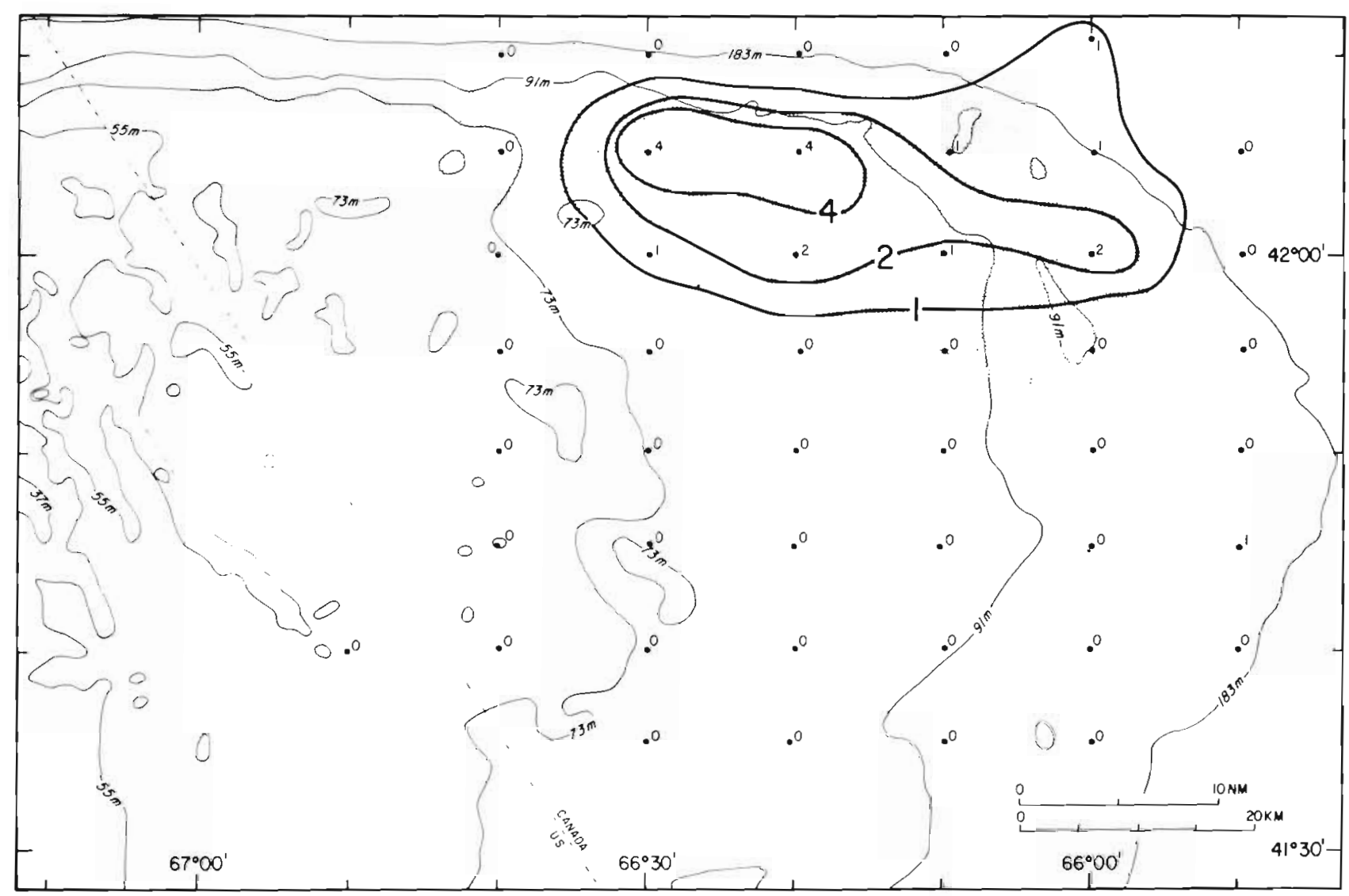

Fig. 7. Map of northeastern Georges Bank showing distribution of demersal juvenile cod from 1-8 Aug, 1986. One aggregation is present, centered on the pebble gravel deposit (shaded area at $42^{\circ} 05^{\prime} \mathrm{N}$ ). Numerical categories at stations: juvenile cod individuals caught in standard research bottom trawls $(3.5$ knots for $30 \mathrm{~min})$ as follows: $0=0$ cod; $1=1$ to $5 ; 2=6$ to $10 ; 3=11$ to $20 ; 4=21$ to 50

western parts of the bank. The distribution of pelagic cod on eastern Georges Bank was remarkably similar in June of both 1986 and 1987 (Fig. 5). The few haddock caught on eastern Georges Bank have a distribution similar to that of cod. In June-July, the pelagic juvenile fish become demersal and are present in abundance on the lag pebble gravel on the northeastern part of the bank. By contrast, at the same time of year, demersal juveniles generally are absent in areas of the bank covered by rippled sand, sand waves and ridges, and gravelly sand.

As noted above, the young fish we observed in late July and early August on the northern edge of the bank remain relatively stationary near the bottom during daytime, stemming the strong tidal current, but they are transported by the current when they rise off the bottom at night.

A trawl survey in late July 1987 showed that 2 aggregations of demersal juvenile cod were present on the bank (Fig. 6); a major one was restricted to the lag gravel deposit $\left(42^{\circ} 05^{\prime} \mathrm{N}\right.$ ), the other was near the eastern end of the bank in an area of varied bottom types.
In early August 1986, a principal aggregation also was centered on the gravel deposit (Fig. 7), but it was located somewhat east of the one observed in July 1987. On the basis of trawl surveys in 1984, juvenile haddock, with minor cod, were present in mid-August on the eastern end of the bank $\left(41^{\circ} 50^{\prime} N\right)$, south of the gravel deposit; in early September, and again in midOctober, they were located progressively farther west along $41^{\circ} 50^{\prime} \mathrm{N}$ (Fig. 8)

Our observations of the diel behavior of the juvenile cod and haddock, and our mapping of their seasonal location on the bank, suggest that aggregations of young demersal gadids drift in the clockwise current gyre of the bank. Thus, the juveniles that settle on the pebble gravel in June and July drift to the east and southeast over the gravel toward the eastern end of the bank, aided by tidal currents and a strong eastward mean current jet (Butman et al. 1982). By mid-August they change direction and move to the west along $41^{\circ} 50^{\prime} \mathrm{N}$ over varied sedimentary environments of sand and sandy gravel. By September-October, the juvenile cod and haddock are near $41^{\circ} 50^{\prime} \mathrm{N}, 66^{\circ} 30^{\prime} \mathrm{W}$ 


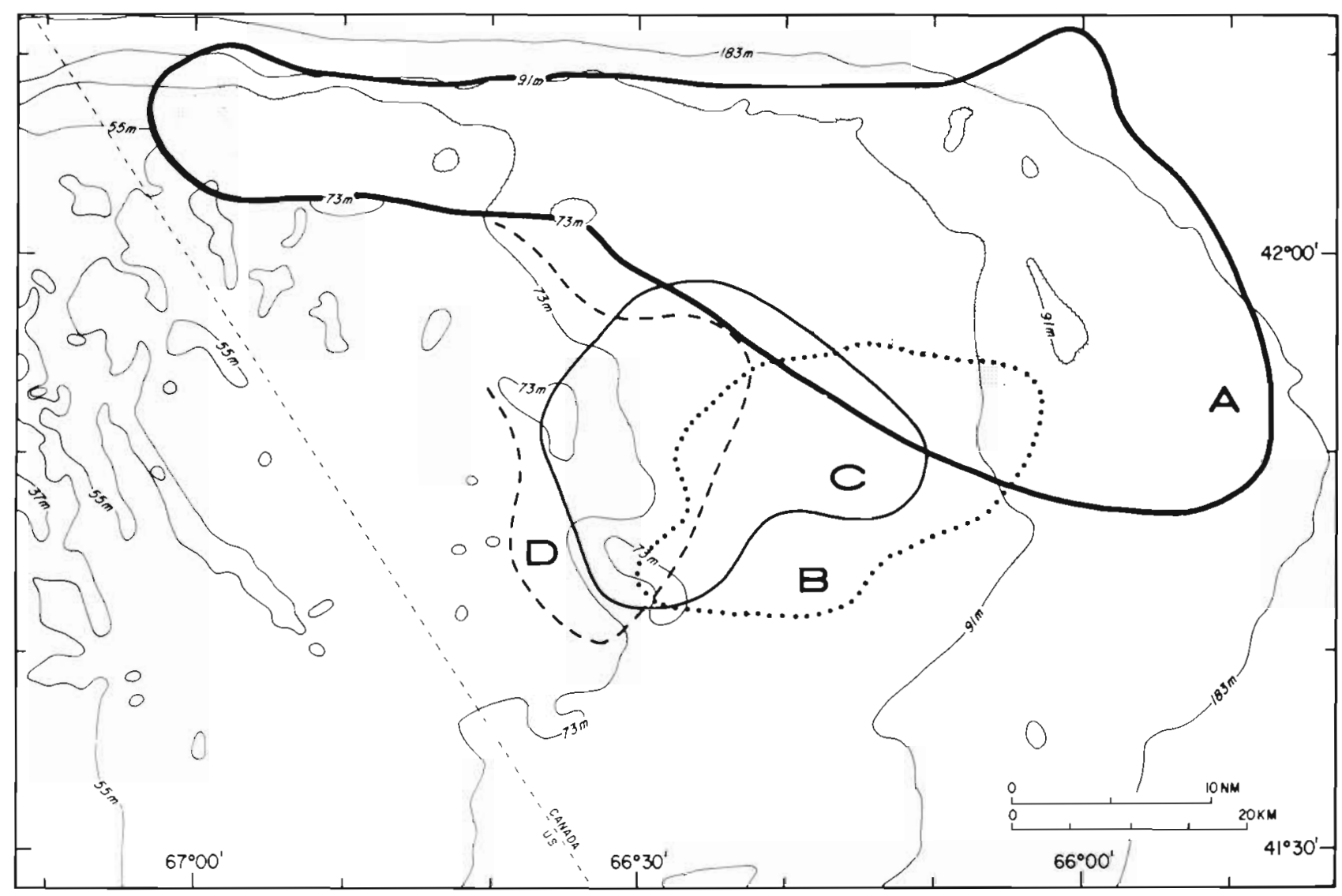

Fig. 8. Generalized distribution, based on research bottom trawl surveys, of demersal juvenile cod and haddock on northeastern Georges Bank from late July through mid-October in relation to the pebble gravel deposit (shaded area). Late July-early August (A) distribution (cod most abundant) is from our 1986 and 1987 combined submersible-trawler study. Late August (B), early September (C), and mid-October (D) distributions (haddock most abundant) are based on surveys in 1984 (Cohen et al. 1985)

and appear to disperse somewhat in an area dominated by sand waves and ridges that is purported to have minimal residual drift (Greenberg 1983).

We have seen that pelagic juvenile gadids are widespread over the bank in June. If they become demersal generally at the same time in June-July, why are they present chiefly on the pebble gravel and poorly represented or absent in other sedimentary environments? We hypothesize that 2 environmental factors could favor the survival of the juvenile fish on the pebble gravel habitat: (1) food availability and/or (2) predation avoidance.

A complex oceanographic frontal system exists along the northern edge of the bank separating Georges Bank water from Gulf of Maine water (Flagg 1987). Cold, nutrient-rich Gulf of Maine Intermediate Water is present along the northern edge (Patusak et al. 1982) which appears to be a principal site for replenishment of Georges Bank water (Hopkins \& Garfield 1981). The extensive gravel deposit described here is in a transition area where the subsurface Gulf of Maine-Georges Bank water front moves northward and southward across the bank edge with the rotary tidal currents (Lough \& Trites 1989). The gravel fauna on the northeastern edge is considered to be one of the richest and most complex benthic communities on Georges Bank (Wigley 1958, 1961, 1968).

Cod and haddock juveniles smaller than 8 to $10 \mathrm{~cm}$ in length generally feed on small prey such as copepods, euphausiids, amphipods, mysids, and cumaceans (Bowman 1981a, b, Mahon \& Neilson 1987, Perry \& Neilson 1988). The young juvenile fish are opportunistic feeders, and they appear to feed primarily on nearbottom invertebrates. In our submersible study, juvenile cod and haddock were active above the bottom following sunset when benthic invertebrates swarmed off the bottom into the water column. Small euphausiids (Meganyctiphanes norvegica) were the predominant prey of the juvenile fish in August, 1986. This prey species is endemic to Georges Bank but is found only in the deeper waters of the bank margins (see Davis 1987). By contrast, in late July 1987, a hyperiid amphipod (Themisto gaudichaudii), was the principal prey. It also is endemic to Georges Bank and 
is found generally in deeper water on the bank margin (see Davis 1987). The larval and juvenile stages of $T$. gaudichaudii are associated with medusae in the plankton, but the adults are free-living and are known to migrate to deeper depths during daylight (see Davis 1987). These types of prey may be most abundant in waters on the gravelly northern edge of Georges Bank where the young juvenile fish are found. However, we do not have data to adequately assess the abundance of prey over the different sedimentary habitats of the bank. As the young juvenile fish are opportunistic feeders and prey chiefly upon near-bottom fauna at this stage in their growth $(<10 \mathrm{~cm}$ in length), their absence in all habitats except the pebble gravel may be related to predator avoidance.

At present, we lend more weight to a predationavoidance hypothesis because the coloration of the juvenile gadids so mimics the mottled appearance of the pebble bottom that it could make them less vulnerable to predation there than on the lighter, more evenly colored sand bottom. The textured pebble bottom is a background that softens fish silhouettes and obscures movement that predators cue on. In our experience, juvenile cod and haddock are difficult to observe in this environment, even with the aid of artificial light. In ambient light, they are almost invisible as they and the gravel bottom appear as shades of gray. Thus, when young demersal fish traverse a local gravel habitat in this region, predation may be reduced, and when they enter a sand area predation may be increased. If predation-avoidance plays an important role, the fate of the geographically dispersed pelagic juvenile cod and haddock depends, in large part, on the characteristics of the sedimentary environment onto which they descend when they become demersal.

The trawl surveys of 1986 and 1987 have shown that the largest known aggregations of recently-settled, demersal juvenile cod and haddock are on the large gravel deposit on eastern Georges Bank. In addition, no recently-settled demersal juvenile fish were observed on sand deposits from the submersible. Presumably, this is because more individuals survive on the gravel than on the sand deposits of the region. It follows that patches of pelagic juvenile gadids that become demersal just to the west of the gravel or on the gravel itself are most favored, as the residual current drift is to the east on the northern edge of the bank. Pelagic juveniles south of the gravel would most likely drift to the south and west and would be less successful in surviving on sand bottoms. Some demersal juveniles may be successful if they settle on or near smaller, as yet unidentified, gravel patches in other parts of the bank.

Based on the foregoing observations, we suggest that the survival of juvenile cod and haddock on Georges
Bank is closely linked to specific current patterns and sedimentary environments as follows:

(1) Pelagic gadid eggs, larvae, and juveniles are dispersed throughout the Georges Bank region in the spring by strong tidal currents and the residual clockwise current gyre. Undetermined numbers of individuals probably are transported off the bank into deep water and perish.

(2) Demersal juvenile gadids that descend in early summer onto the lag pebble-gravel habitat for are transported there by bottom currents) resemble the mottled bottom in coloration. Here they may be less vulnerable to predation, particularly by species such as silver hake Merluccius bilinearis (Edwards \& Bowman 1979), and the numerous yearling cod we observed near the bottom, than are those juveniles that settle onto sand areas. The gravel deposit along the northern edge of Georges Bank and the fauna associated with the Gulf of Maine-Georges Bank frontal system could be essential to the recruitment success of juvenile cod and haddock.

(3) Demersal juveniles that inhabit the western and central part of the large gravel deposit on northeastern Georges Bank in June-July are transported during the summer to the east and southeast across the gravel by strong tidal and along-shelf currents. In the fall, they are transported westward across a variety of sandy and gravelly habitats and, presumably, disperse across the bank as they mature.

This study documents the transport of juvenile gadids on eastern Georges Bank and indicates the importance of sedimentary environments to the survival of recently-settled juveniles. The results presented here provide a basis, and an impetus, for further investigation into the roles of habitat type and distribution, predator avoidance, and food availability in relation to successful recruitment of juvenile gadids. Moreover, a knowledge of the diel behavior, geographic location, and most favorable habitat of demersal 0-group juveniles is important for improving the assessment and management of the Georges Bank gadid population.

Acknowledgements. We thank the crews of the RV 'Edwin Link' and the submersible 'Johnson-Sea-Link I', the RV 'Powell' and submersible 'Delta', and the RV 'Delaware II' Submersible cruises were funded by the NOAA National Undersea Research Program. This is MARMAP contribution FED, NEFC 88-10.

\section{LITERATURE CITED}

Bolz, G. R., Lough, R. G. (1988). Growth through the first six months of Atlantic cod, Gadus morhua, and haddock, Melanogrammus aeglefinus, based on daily otolith increments. Fish. Bull. U.S. 86: 223-235

Bowman, R. E. (1981a). Food and feeding of 0-group haddock 
in the northwest Atlantic. Rapp. P.-v. Réun. Cons. perm. int. Explor. Mer 178: 322-323

Bowman, R. E. (1981b). Food of 10 species of northwest Atlantic juvenile groundfish. Fish. Bull. U.S. 79: 200-206

Brown, B. E. (1987). The fisheries resources. In: Backus, R. H. (ed.) Georges Bank. The MIT Press, Cambridge, p. $480-493$

Brown, W. S., Moody, J. A. (1987). Tides. In: Backus, R. H. (ed.) Georges Bank. The MIT Press, Cambridge, p. 100-107

Butman, B. (1987). Physical processes causing surficial sediment movement. In: Backus, R. H. (ed.) Georges Bank. The MIT Press, Cambridge, p. 147-162

Butman, B., Beardsley, R. C., Magnell, B., Frye, D., Vermersch, J. A., Schlitz, R., Limeburner, R., Wright, W. R., Noble, M. A. (1982). Recent observations of the mean circulation on Georges Bank. J. phys. Oceanogr. 12: $569-591$

Canadian Hydrographic Service (1985). Hydrographic Chart L/C-8005, 1 sheet, scale 1:300,000

Cohen, E. B., Green, J. R., Potter, D. C. Hayden, B. P. (1985). Some preliminary results of juvenile cod and haddock studies on Georges Bank in 1984 and 1985. Int. Coun. Explor. Sea Comm. Meet. G 74:23

Colton, J. B., JI (1965). The distribution and behavior of pelagic and early demersal stages of haddock in relation to sampling techniques. Int. Comm. Northw. Atl. Fish. Spec. Pub. 6: 318-333

Davis, C. A. (1987). Zooplankton life cycles. In: Backus, R. H. (ed.) Georges Bank. The MIT Press, Cambridge, p. 256-267

Edwards, R. L., Bowman, R. E. (1979). Food consumed by continental shelf fishes. In: Clepper, $\mathrm{H}$. (ed.) Predator-prey systems in fish communities and their role in fisheries management. Sports Fishing Int., Washington, D.C., p. $387-406$

Fader, G. B. H., King, E., Gillespie, R., King, L. H. (1988). Surficial geology of Georges Bank, Browns Bank, and the southeastern Gulf of Maine. Geol. Surv. Canada, Open File 1692, 3 sheets

Fahay, M. P. (1983). Guide to the early stages of marine fishes occurring in the western North Atlantic, Cape Hatteras to the southern Scotian Shelf. J. Northw. Atl. Fish. Sci. 4: $1-4.23$

Flagg, C. N. (1987). Hydrographic structure and variability. In: Backus, R. H. (ed.) Georges Bank. The MIT Press, Cambridge, p. 108-124

Greenberg, D. A. (1983). Modeling the mean barotropic circulation in the Bay of Fundy and Gulf of Maine. J. phys. Oceanogr 13: 886-904

Grosslein, M. D. (1974). Bottom trawl survey methods of the Northeast Fisheries Center, Woods Hole, Massachusetts, USA. Int. Comm. Northw. Atl. Fish. Res. Doc. 74/96, No. 3332: $1-27$

Hathaway, J. C., ed. (1966). Data file, Continental Margin Program, Atlantic Coast of the United States, Vol. 1, Sample collection data. Woods Hole Oceanogr. Inst. Ref. No. 66-8

Hennemuth, R. C., Palmer, J. E., Brown, B. E. (1980). A statistical description of recruitment in eighteen selected fish stock.s. J. Northw. Atl. Fish. Sci. 1: 101-111

Hopkins. T. S., Garfield III, N. (1981). Physical origins of Georges Bank Water J. mar. Res. 39: 465-500

Hunter, J. R. (1972). Swimming and feeding behaviour of larval anchovy Engraulis mordax. Fish. Bull. U.S. 70: $821-838$

Jordan, G. F. (1962). Large submarine sand waves. Science 136: $839-848$
Koeller, P. A. Hurley, P. C. F., Perley, P., Neilson, J. D. (1986). Juvenile fish surveys on the Scotian Shelf: implications for year-class assessments. J. Cons. int. Explor. Mer 43: 59-76

Lewis, R. S., Sylwester, R. E., Aaron, J. M., Twichell, D. C., Scanlon, K. M. (1980). Shallow sedimentary framework and related potential geologic hazards in the Georges Bank area. In: Aaron, J. M. (ed.) Environmental geologic studies in the Georges Bank area, United States northeastern Atlantic outer continental shelf, 1975-1977 U.S. Geol. Surv. Open File Report 80-240

Lough, R. G. (1984). Larval fish trophodynamic studies on Georges Bank: sampling strategy and initial results. In: Dahl, E., Danielssen, D. S., Moksness, E., Solemdal, P. (eds.) The propagation of cod Gadus morhua L. Flodevigen rapportser $1 \cdot 395-434$

Lough, R. G., Trites, R. W. (1989) Chaetognaths and oceanography on Georges Bank. J. mar. Res. 47: 343-369

Mahon, R., Neilson, J. D. (1987). Diet changes in Scotian Shelf haddock during the pelagic and demersal phases of the first year of life. Mar. Ecol. Prog. Ser. 37: 123-130

Moody, J. A., Butman, B., Beardsley, R. C., Brown, W. S., Daifuku, P., Irish, J. D., Mayer, D. A., Mofjeld, H. O., Petrie, B., Ramp, S., Smith, P., Wright, W. R. (1984). Atlas of tidal elevation and current observations on the northeast American continental shelf and slope. U.S. Geol. Surv. Bull. 1611: 1-122

Overholtz, W. J. (1985). Seasonal and age-specific distribution of the 1975 and 1978 year-classes of haddock on Georges Bank. NAFO Sci. Coun. Studies 8: 77-82

Patusak, M., Wright, W. R, Patanjo, D. (1982). One year of nutrient distribution in the Georges Bank region in relation to hydrography, 1975-1976. J. mar. Res. 40 (Suppl.): 525-542

Perry, R. 1., Neilson, J. D. (1988). Vertical distributions and trophic interactions of age-0 Atlantic cod and haddock in mixed and stratified waters of Georges Bank. Mar Ecol. Prog. Ser. 49: 199-214

Potter, D. C., Lough, R. G., Perry, R. I., Neilson, J. D. (1989). Comparison of the MOCNESS and IYGPT pelagic samplers for the capture of 0 -group cod (Gadus morhua) on Georges Bank. J. Cons. (in press)

Schlee, J. (1973). Atlantic continental shelf and slope of the United States - sediment texture of the northeastern part. U.S. Geol. Surv. Prof. Paper 529-L.

Schlee, J., Pratt, R. M. (1970). Atlantic continental shelf and slope of the United States -- gravels of the northeastern part. U.S. Geol. Surv. Prof. Paper 529-H

Scott, J. S. (1984). Short-term changes in distribution, size, and availability of juvenile haddock around Sable Island off Nova Scotia. J. Northw. Atl. Fish. Sci. 5: 109-112

Sherman, K., Smith, W., Morse, W., Berman, M. S., Green, J. R., Ejsymont, L. (1984). Spawning strategies of fishes in relation to circulation, phytoplankton production, and pulses in zooplankton off the northeastern United States. Mar. Ecol. Prog. Ser 18: 1-19

Smith, W. Morse, W. W. (1985). Retention of larval haddock Melanogrammus aeglefinus in the Georges Bank region, a gyre-influenced spawning area. Mar. Ecol. Prog. Ser. 24: $1-13$

Twichell, D. C. (1983). Bedform distribution and inferred sand transport on Georges Bank, United States Atlantic continental shelf. Sedimentology 30:695-710

Tyler, P. (1978). The influence of swimming performance on the metabolic rate of gadoid fish. In: McLusky, D. S., Berry, A. J. (eds.) Physiology and behaviour of marine organisms. Pergamon Press, Oxford, p. 83-92 
Uzmann, J. R., Cooper, R. A., Theroux, R. B., Wigley, R. L. (1977). Synoptic comparison of three sampling techniques for estimating abundance and distribution of selected megafauna: submersible vs. camera sled vs. otter trawl. Mar Fish. Rev. 39; 11-19

Wigley, R. L. (1958). Georges Bank bottom fauna. In: Graham,

This article was presented by Dr K. Sherman, Narragansett, Rhode Island, USA
H. W. (dir.) Woods Hole Laboratory Annual Report. U.S Dept. Interior, Fish and Wildife Service, p. 55-58 Wigley, R. L. (1961). Bottom sediments of Georges Bank. J. sedim. Petrol. 31 165-1288

Wigley, R. L. (1968). Benthic invertebrates of the New England fishing banks. Underwat. Nat. 5: 8-13

Manuscript first received: January 26, 1989 Revised version accepted: May 20, 1989 